Jurnal Dinamika Sosial Ekonomi Vol.20 No.1, Juni 2019 : 55-64

ISSN 1411-593X (print)

\title{
ANALISIS DAN MITIGASI RISIKO RANTAI PASOK KAKAO DI GRIYA COKELAT NGLANGGERAN GUNUNGKIDUL YOGYAKARTA
}

\section{Analysis and Mitigation of Supply Chain Risk of Cacao in Griya Cokelat Nglanggeran Gunungkidul Yogyakarta}

\author{
Linda Eka Farhana, Nanik Dara Senjawati*, Heni Handri Utami \\ Program Studi Agribisnis, Fakultas Pertanian, \\ Universitas Pembangunan Nasional "Veteran" Yogyakarta \\ Jl. Padjadjaran (Lingkar Utara 104) Condongcatur, Yogyakarta \\ email korespondensi : darasenjawati@gmail.com
}

Diterima tanggal : 14 Februari 2019 ; Disetujui tanggal : 3 Mei 2019

\begin{abstract}
This research was conducted in Griya Cokelat Nglanggeran, Nglanggeran Village, district of Patuk, Gunungkidul which is processes cacao into various of final products. The aims of this research are to identifying supply chain of cacao in Griya Cokelat Nglanggeran, analyzing risks of farmers, analyzing risks of kelompok tani, analyzing risks of Gabungan Kelompok Tani, analyzing risks of Griya Cokelat Nglanggeran and analyzing risks of retailer. The basic method of this research is descriptive and did with case study method with quantitative approach. The selection of respondents was did by purposive sampling technique. The technique of data collection used were observations, in depth interviews questionnaires and literature reviews. The results of this research are in farmers, there are 8 risks with 2 extreme statuses. In Kelompok Tani, there are 10 risks without extreme statuses of risk. In Gabungan Kelompok Tani, there are 10 risks with 2 extreme statuses. In Griya Cokelat Nglanggeran, there are 17 risks with 2 extreme statuses. In retailer, there are 8 risks without extreme statuses. Risk mitigation is prepared to reduce risk status of each risk through risk matrix.
\end{abstract}

Keywords: Cacao, Risk Mitigation, Supply Chain,

\begin{abstract}
ABSTRAK
Penulisan ini dilakukan di Griya Cokelat Nglanggeran Desa Nglanggeran, Kecamatan Patuk Kabupaten Gunungkidul yang mengolah kakao menjadi berbagai produk olahan. Tujuan dari penulisan ini adalah untuk mengidentifikasi rantai pasok kakao di Griya Cokelat Nglanggeran, menganalisis risiko pada petani, menganalisis risiko pada kelompok tani, menganalisis risiko pada Gabungan Kelompok Tani dan menganalisis risiko pada retailer. Metode dasar penulisan ini adalah metode deskriptif dan dilaksanakan dengan metode studi kasus melalui pendekatan kuantitatif. Pemilihan responden dilakukan menggunakan teknik purposive sampling. Metode pengambilan data dengan observasi, wawancara in depth interview, kuesioner dan studi pustaka. Hasil
\end{abstract}


penulisan ini menunjukkan bahwa pada komponen petani terdapat 8 kejadian risiko dengan 2 risiko berstatus ekstrem. Pada kelompok tani terdapat 10 kejadian risiko tanpa status ekstrem, pada Gabungan Kelompok Tani terdapat 10 kejadian risiko dengan 2 status ekstrem. Pada Griya Cokelat Nglanggeran terdapat 17 kejadian risiko dengan 2 status ekstrem. Pada komponen retailer terdapat 8 kejadian risiko tanpa status ekstrem. Mitigasi risiko disusun untuk menurunkan status risiko pada setiap kejadian risiko menggunakan matriks risiko.

Kata kunci: Kakao, Mitigasi Risiko, Rantai Pasok

\section{PENDAHULUAN}

Manajemen rantai pasok merupakan sautu konsep yang berkaitan dengan pola distribusi produk yang mampu menggantikan pola-pola pendisitribusian barang secara tradisional. Pola yang baru ini berkaitan dengan aktivitas pendistribusian, jadwal produksi dan logistik (Ulfah, et.al., 2016). Rantai pasok yang efektif merupakan salah satu perspektif yang digunakan untuk meningkatkan competitive advantage untuk menjaga keberlangsungan sebuah usaha (Pujawan, 2005). Pada proses rantai pasok terdapat berbagai risiko yang ditemui yang dapat mempengaruhi rantai pasok tersebut tidak dapat berjalan secara lancar (Ulfah et.al., 2016). Risiko rantai pasok merupakan tindakan pelaku rantai pasok dan lingkungannya atau kejadian yang menyebabkan kerusakan dan berpengaruh negatif terhadap proses bisnis dalam rantai pasok. Manajemen rantai pasok pada komoditas pertanian memiliki perbedan dengan produk non pertanian dikarenakan (1) mudah rusak, (2) proses penanaman, pertumbuhan dan pemanenan tergantung pada iklim dan musim (3) hasil dan panen memiliki bentuk dan ukuran yang bervariasi, ( produk pertanian memiliki sifat kamba sehingga sulit untuk ditangani (Austin, 1992; Brown, 1994 dalam Suharjito, et.al., 2011). Sebagai industri kuliner yang merupakan turunan dari produk pertanian, rantai pasok di dalamnya lebih rentan mengalami berbagai risiko pada setiap komponennya. Pada Griya Cokelat Nglanggeran, risiko ini merupakan faktor-faktor yang menghambat operasional pada rantai pasok kakao, yang mana risiko pada rantai pasok ini terjadi mulai dari petani, kelompok tani, gabungan kelompok tani, Griya Cokelat Nglanggeran dan retailer. 
Penilaian terhadap risiko-risiko yang terjadi dalam aktivitas rantai pasok penting dilakukan agar diketahui dampak dan penyebab risiko sehingga dapat dilakukan mitigasi risiko dan perbaikan sistem rantai pasok untuk perkembangan perusahaan. Oleh karena itu, perlu dilakukan penelitian mengenai risiko rantai pasok kakao di Griya Cokelat Nglanggeran dengan judul "Analisis dan Mitigasi Risiko Rantai Pasok Kakao di Griya Cokelat Nglanggeran Gunungkidul Yogyakarta". Tujuan penelitian ini adalah untuk mengidentifikasi rantai pasok kakao di Griya Cokelat Nglanggeran, menganalisis risiko pada petani, menganalisis risiko pada kelompok tani, menganalisis risiko pada Gabungan Kelompok Tani, menganalisis risiko pada Griya Cokelat Nglanggeran dan menganalisis risiko pada retailer.

\section{METODE PENELITIAN}

Metode dasar penelitian yang digunakan dalam penelitian ini adalah metode deskriptif yang dilaksanakan menggunakan studi kasus. Penentuan responden dalam penelitian ini menggunakan nonprobability sampling dengan teknik purposive sampling. Metode pengumpulan data dilakukan melalui observasi, in depth interview, kuesioner dan studi pustaka. Analisis data dilakukan melalui beberapa tahap, yaitu identifikasi sistem dan pelaku rantai pasok dengan Supply Chain Operation Reference, identifikasi kejadian dan sumber risiko, analisis risiko dengan pendekatan Risk Failure Mode and Effect Analysis dan pemetaan risk matrix menggunakan matriks risiko 5 x 5 .

\section{HASIL DAN PEMBAHASAN}

Hasil penelitian menunjukkan bahwa rantai pasok kakao di Griya Cokelat Nglanggeran dilakukan oleh 5 (lima) komponen utama, yaitu petani, kelompok tani, Gabungan Kelompok Tani, Griya Cokelat Nglanggeran dan retailer. Setiap komponen rantai pasok memiliki risiko yang berbeda, tergantung aktivitas bisnisnya. Hasil penelitian dari pengukuran nilai occurrence (seberapa sering risiko terjadi) dan nilai severity (seberapa parah dampaknya apabila risiko tersebut terjadi) dipetakan dalam sebuah matriks risiko 5 x 5 . Pada matriks ini, masing- 
masing risiko akan dipetakan berdasarkan statusnya saat ini dan dipetakan status ekspektasinya setelah dilakukan mitigasi dengan asumsi mitigasi yang dijalankan berhasil. Berikut adalah keterangannya:

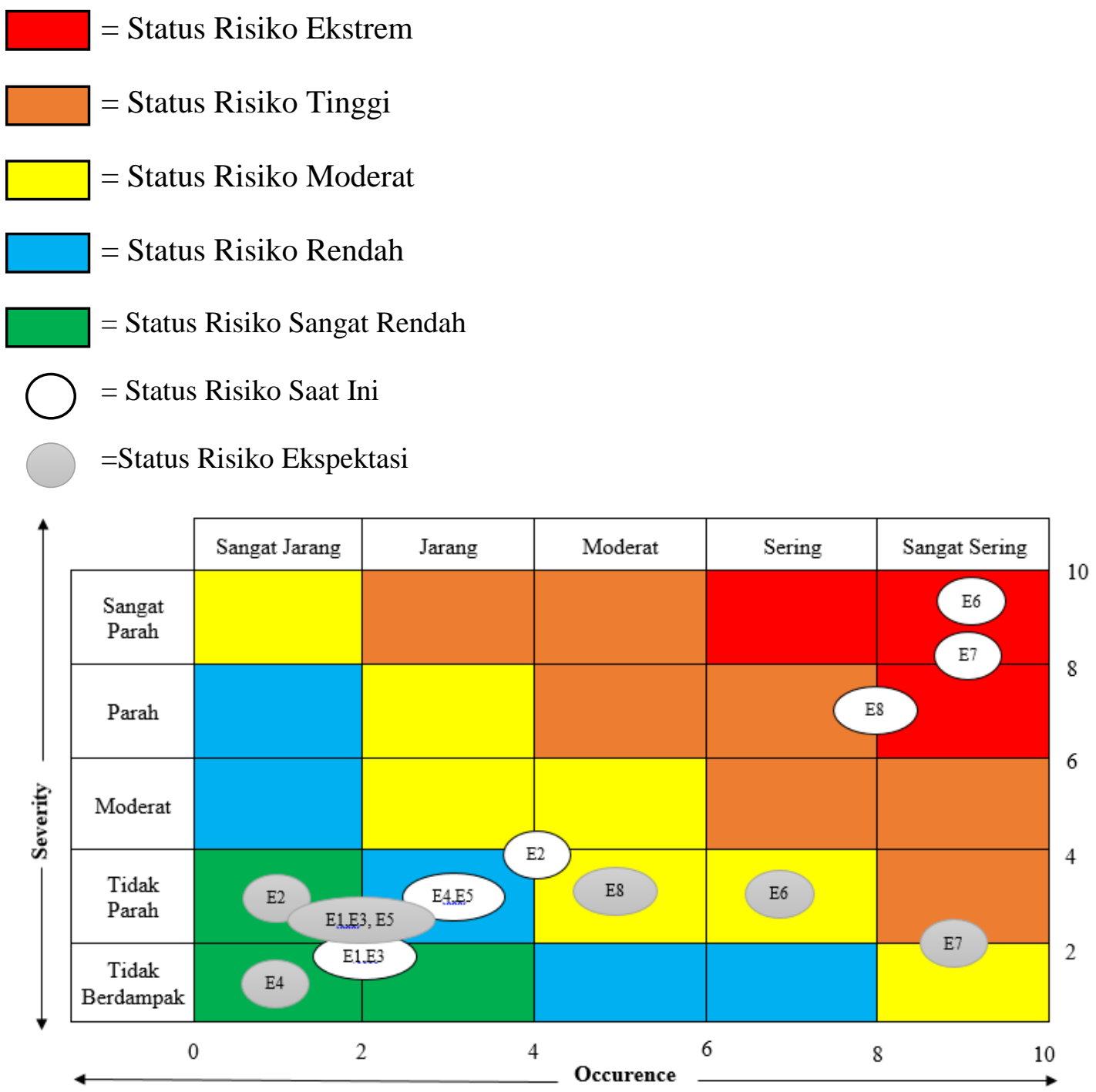

Gambar 1. Matriks Risiko pada Petani

Pada komponen petani, terdapat 8 (delapan) kejadian risiko dengan 2 (dua) kejadian risiko bertatus ekstrem, yaitu risiko terserang hama dan penyakit serta risiko curah hujan terlalu tinggi. Saran mitigasi risiko dari kejadian risiko ini sebagaimana yang dijelaskan Aini et.al., (2104) adalah dengan memberikan penyuluhan kepada petani untuk meningkatkan keterampilan, pengetahuan, dan 
informasi untuk menangani permasalahan danmeningkatkan produktivitas kakao. Saran mitigasi risiko dari kejadian risiko ini adalah dengan melakukan diversifikasi pohon pelindung, seperti pohon durian, mahoni dan sirsak.

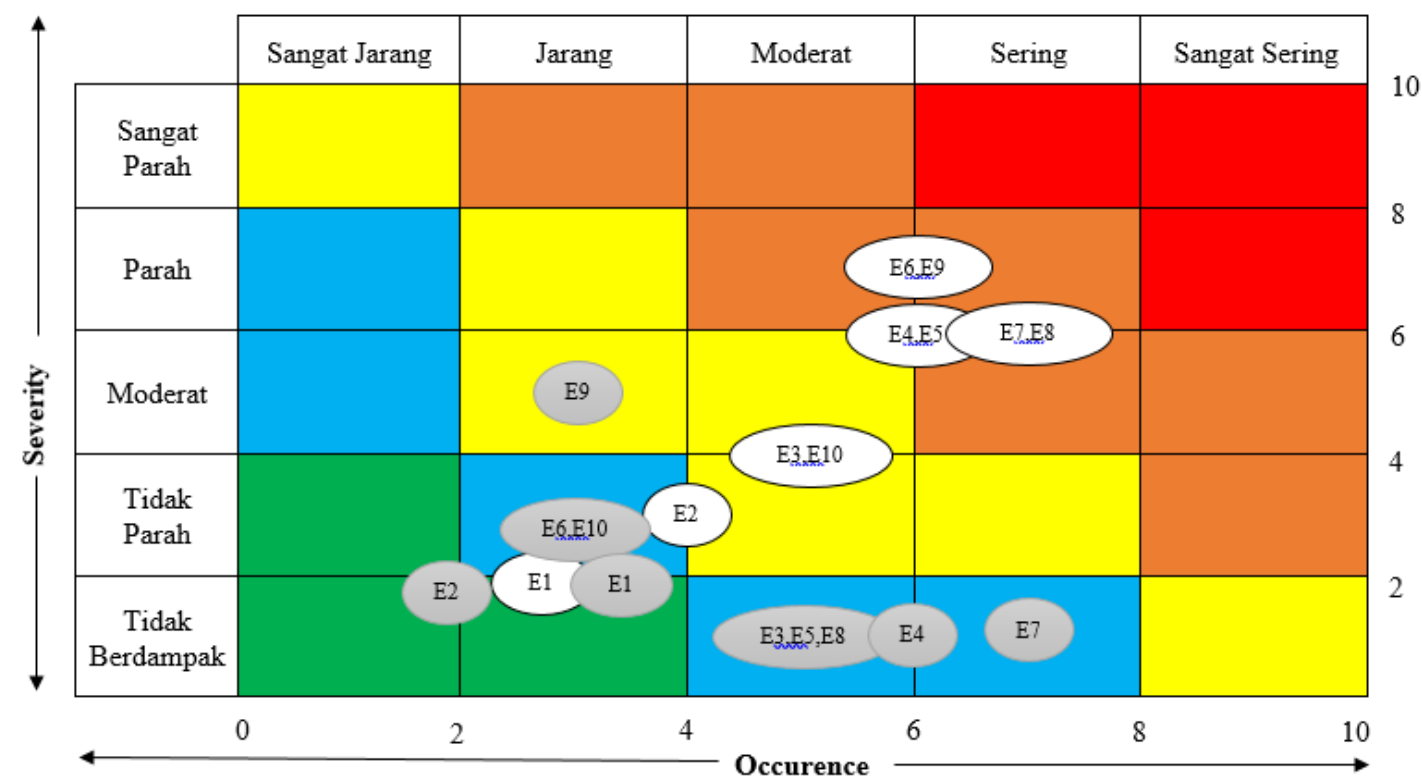

Gambar 2. Matriks pada Kelompok Tani

Pada komponen kelompok tani terdapat 10 (sepuluh) kejadian risiko dengan 2 (dua) kejadian risiko berstatus tinggi, yaitu proses fermentasi tidak sempurna dan jumlah produk yang dikirim tidak sesuai pesanan Gapoktan. Saran mitigasi risiko pada kejadian risiko ini adalah penyusunan SOP fermentasi. Kegagalan fermentasi ini juga mengakibatkan kejadian risiko berstatus tinggi lainnya, yaitu jumlah produk yang dikirim tidak sesuai dengan pesanan Gapoktan, oleh karena itu, saran mitigasi pada kejadian risiko ini berupa pelatihan keterampilan fermentasi bagi pengurus kelompok tani supaya angka kegagalan fermentasi dapat diturunkan. 


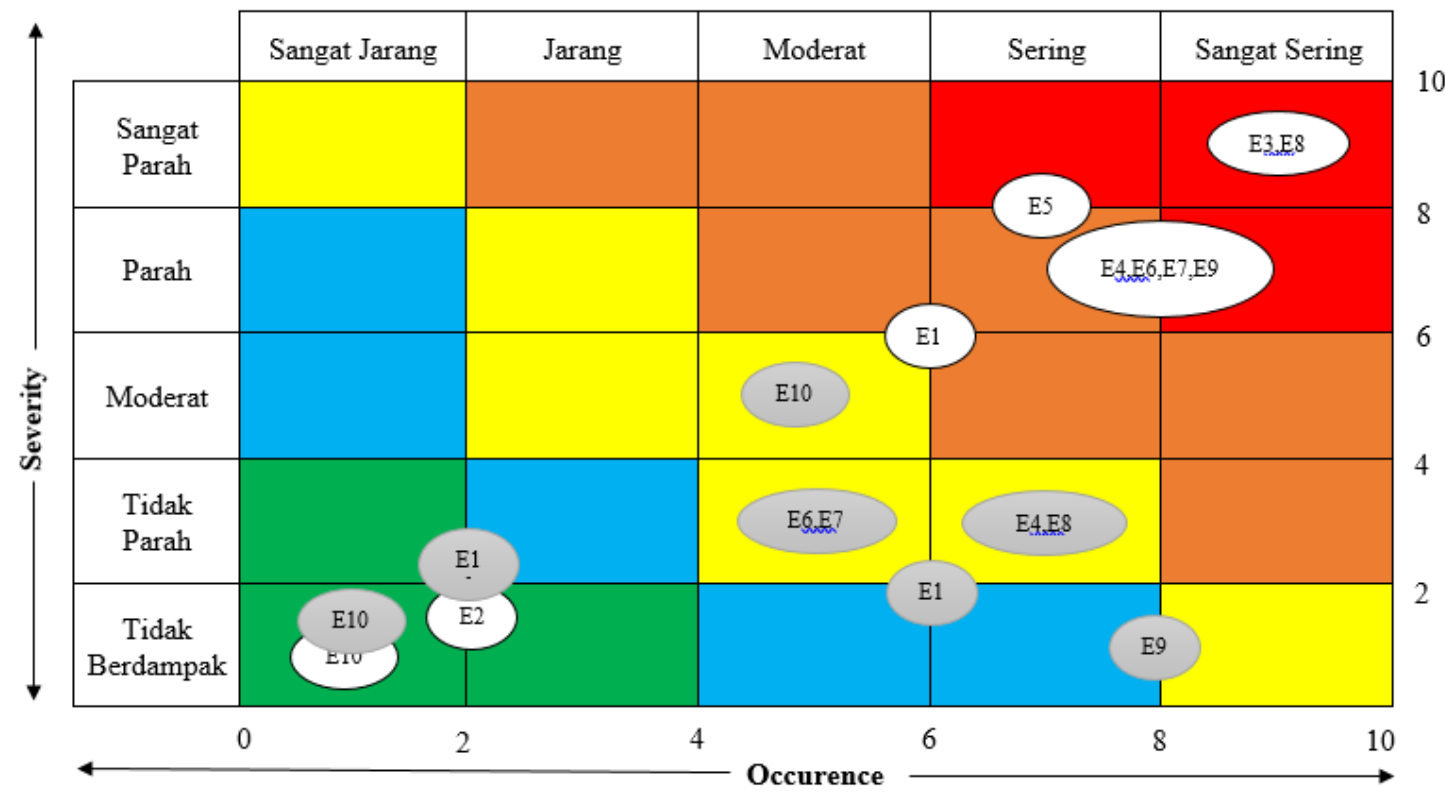

Gambar 3. Matriks pada Gabungan Kelompok Tani

Pada Gabungan Kelompok Tani terdapat 10 kejadian risiko dengan 2 kejadian risiko berstatus ekstrem, yaitu risiko pelatihan tenaga kerja dan risiko terjadinya kerusakan mesin. Saran mitigasi untuk kejadian risiko ini adalah pelatihan pembubukan kakao kepada pengurus Gabungan Kelompok Tani dan penambahan jumlah petugas pembubuk. Kejadian risiko ekstrem lainnya adalah terjadi kerusakan mesin. Saran mitigasi risiko ini adalah penambahan peralatan pembubukan, perawatan rutin mesin pembubukan.

Pada Griya Cokelat Nglanggeran terdapat tujuh belas kejadian risiko dengan 2 kejadian risiko ekstrem, yaitu pemadaman listrik dan terjadi kerusakan mesin. Saran mitigasi dari kejadian risiko ini adalah penyediaan genset ketika terjadi pemadaman. Kejadian risiko ekstrem selanjutnya adalah kerusakan mesin. Saran mitigasi dari kejadian risiko ini adalah perawatan mesin dan peralatan lainnya secara berkala. 


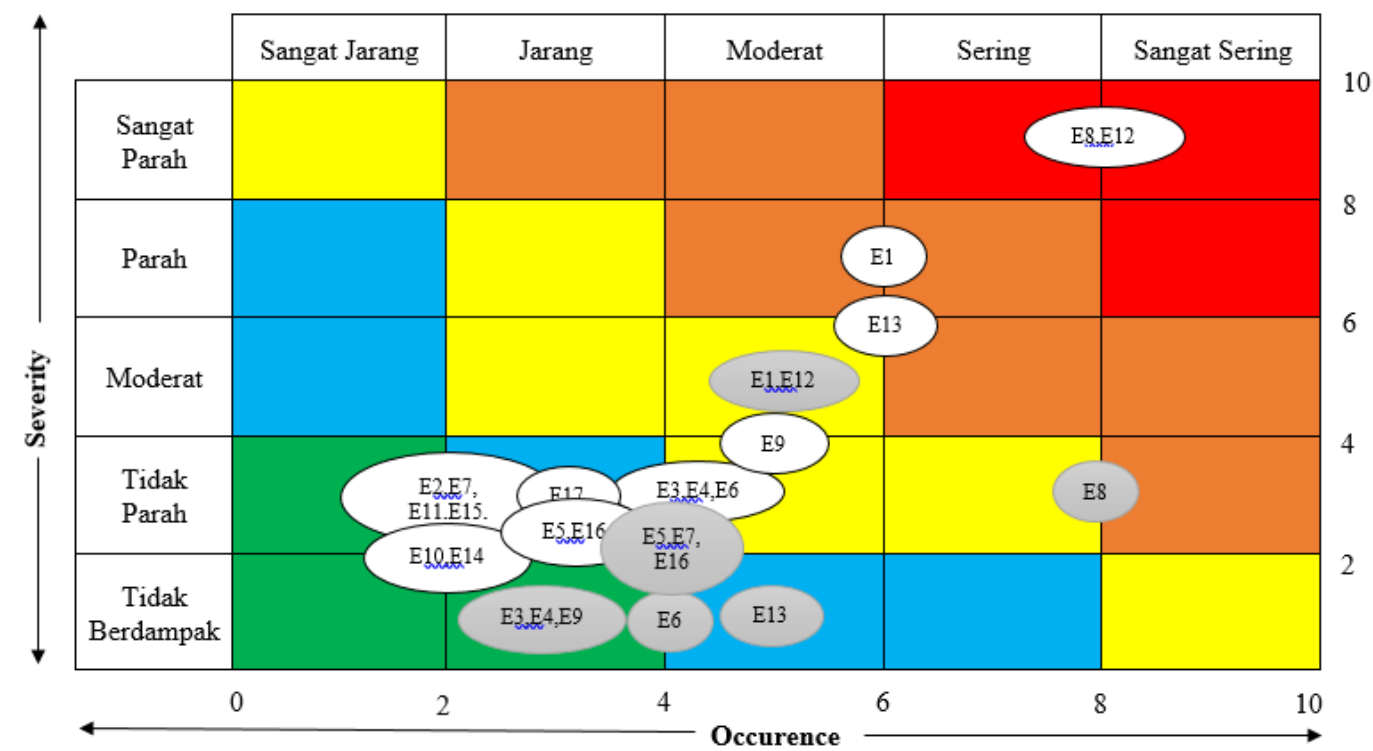

Gambar 4. Matriks Risiko pada Griya Cokelat Nglanggeran

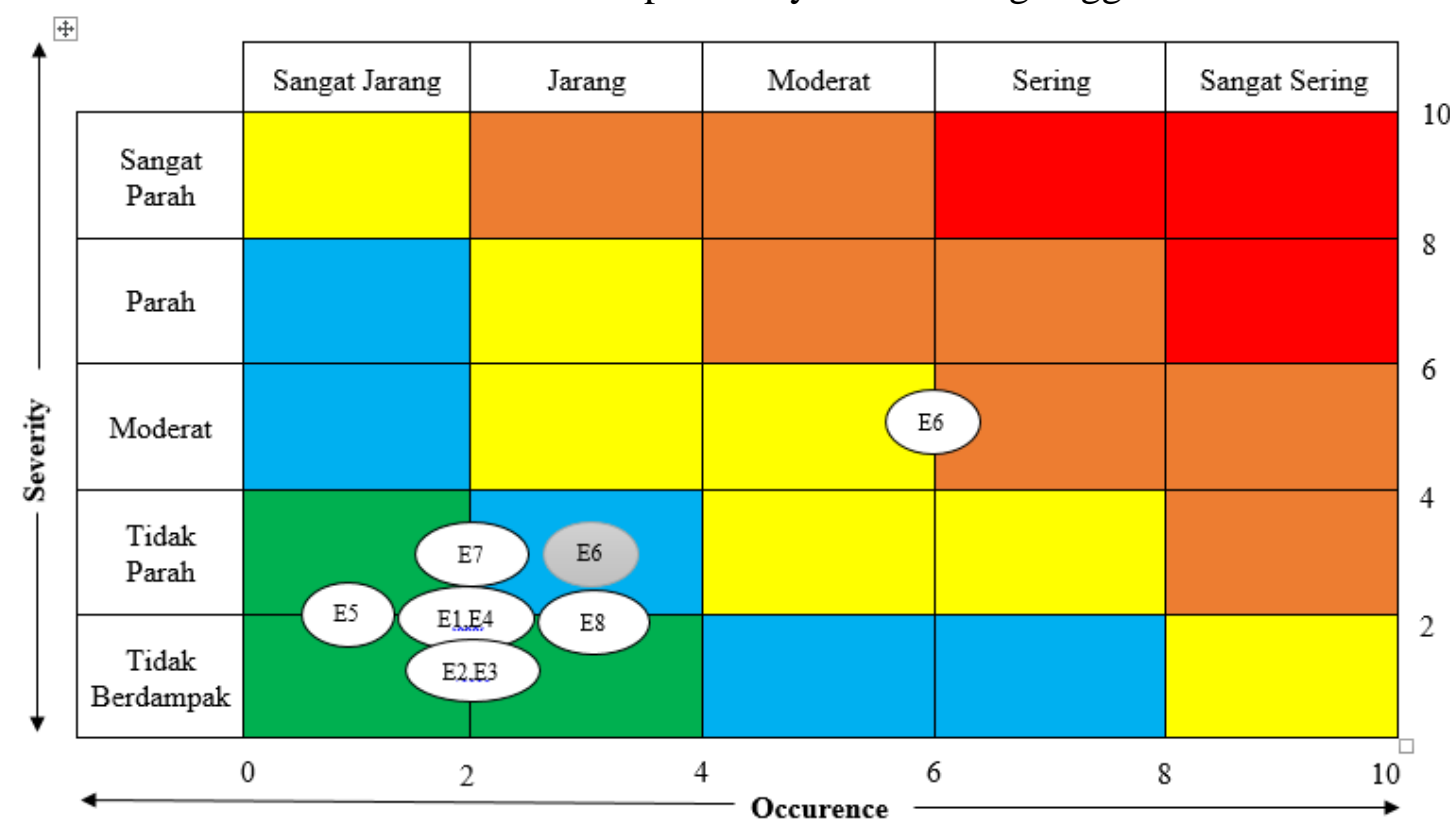

Gambar 5. Matriks Risiko pada Retailer

Pada retailer tidak terdapat kejadian risiko ekstrem. Penilaian kejadian risiko tertinggi adalah pada kejadian risiko terjadi kerusakan dalam pengiriman yang disebabkan oleh tidak adanya SOP (Standard Operation Procedure) pengiriman yang disetujui kedua belah pihak, yaitu antara Griya Cokelat Nglanggeran sebagai pengirim dan retailer sebagai penerima. 
Menurut Aklimawati (2013), potensi ekonomi komoditas kakao umunya ada pada harga dan peluang pasar. Dilihat dari sisi harga, faktor ini yang menarik minat petani untuk menanam dan membudidayakan kakao secara berkelanjutan. Harga jual biji kakao di tingkat petani sangat dipengaruhi oleh kualitas biji kakao yang dihasilkan oleh petani. Semakin baik atau kering biji kakao petani maka harga jualnya semakin tinggi (Herawati, et.al., 2015).

\section{KESIMPULAN DAN SARAN}

\section{Kesimpulan}

Skema rantai pasok kakao di Desa Nglanggeran yaitu terdiri dari 5 (lima) komponen. Petani berperan sebagai supplier 1, kelompok tani berperan sebagai supplier 2, Gabungan Kelompok Tani berperan supplier 3, Griya Cokelat Nglanggeran berperan sebagai manufacturer dan retailer bertugas untuk mendistribusikan produk serta menjualnya kepada konsumen. Ada 8 (delapan) kejadian risiko rantai pasok kakao pada tingkat petani yang disebabkan oleh 9 (sembilan) agen risiko. 2 (dua) kejadian risiko berstatus ekstrem. Ada 10 (sepuluh) kejadian risiko rantai pasok kakao pada tingkat kelompok tani yang disebabkan oleh 10 (sepuluh) agen risiko. Tidak ada risiko bertstaus ekstrem, Ada 10 (sepuluh) kejadian risiko rantai pasok kakao pada tingkat Gabungan Kelompok Tani yang disebabkan oleh 9 (sembilan) agen risiko. 2 (dua) kejadian risiko berstatus ekstrem Ada 17 (tujuh belas) kejadian risiko rantai pasok kakao pada tingkat Griya Cokelat Nglanggeran yang disebabkan oleh 14 (Empat Belas) agen risiko. 2 (dua) kejadian risiko berstatus ekstrem. Ada 8 (delapan) kejadian risiko rantai pasok kakao pada tingkat retailer yang disebabkan oleh 7 (tujuh) agen risiko. Tidak ada risiko berstatus ekstrem.

\section{Saran}

Petani diharapkan dapat menerapkan strategi mitigasi penggunaan pestisida hayati, diversifikasi, penambahan pohon pelindung (pohon durian, mahoni, sirsak), penggunaan pestisida hayati, penyelubungan buah dengan kantong plastik, pemanfaatan agen hayati semut hitam dan jamur Beauveria, 
penyusunan jadwal kerja harian secara berkala, penggunaan sarana produksi dari sumber daya lokal dan pengaturan jarak tanam dan pemilihan bibit kualitas unggul supaya status risiko setiap kejadian dapat turun sesuai hasil matriks ekspektasi mitigasi risiko.

Kelompok tani diharapkan dapat menerapkan strategi mitigasi penyusunan SOP (Standar Operation Procedure) fermentasi, pelatihan keterampilan fermentasi bagi pengurus kelompok tani, pembuatan rangkaian pencahayaan buatan, pembuatan kotak fermentasi sederhana, perluasan kerja sama dengan petani kakao dan pembuatan buku keuangan sederhana supaya status risiko setiap kejadian dapat turun sesuai hasil matriks ekspektasi mitigasi risiko. Gabungan Kelompok Tani diharapkan dapat menerapkan strategi mitigasi pelatihan pembubukan kakao kepada pengurus Gabungan Kelompok Tani, penambahan jumlah petugas pembubuk, penambahan peralatan pembubukan, perawatan rutin mesin pembubukan, perluasan kerja sama dengan kelompok tani, penyusunan SOP (Standard Operation Procedure) pembubukan dan penerapan manajemen stock sederhana oleh Gapoktan supaya status risiko setiap kejadian dapat turun sesuai hasil matriks ekspektasi mitigasi risiko.

Griya Cokelat Nglanggeran diharapkan dapat menerapkan strategi mitigasi penyediaan alat bantu genset, perawatan mesin dan peralatan secara berkala, perluasan segmentasi pasar, penyusunan SOP (Standard Operational Procedure) pengolahan, penyusunan peraturan kerja bagi karyawan, perluasan kerja sama pemasok bubuk kakao dan pembuatan buku keuangan sederhana supaya status risiko setiap kejadian dapat turun sesuai hasil matriks ekspektasi mitigasi risiko. Retailer diharapkan dapat menerapkan strategi mitigasi penyusunan SOP pengiriman antara Griya Cokelat Nglanggeran dan retailer supaya status risiko setiap kejadian dapat turun sesuai hasil matriks ekspektasi mitigasi risiko.

\section{DAFTAR PUSTAKA}

Aini, H., Syamsun, M., dan Setiawan, A. (2014). Risiko Rantai Pasok Kakao Di Indonesia dengan Metode Analytic Network Process Dan Failure Mode Effect Analysis Terintegrasi. Jurnal Manajemen dan Agribisnis, 11 (3) : 209-219. 
Aklimawati, L. (2013). Potensi Ekonomi Kakao sebagai Sumber Pendapatan Petani. Jurnal Warta, 25(2) : 25-30.

Anonim. (2017). Administrator Desa Nglanggeran. Gunung Kidul : Pemerintah Desa Nglanggeran.

Herawati, Rifin, A., dan Tinaprilla, N. (2015). Kinerja dan Efisiensi Rantai Pasok Biji Kakao di Kabupaten Pasaman, Sumatera Barat. J TIDP, 2 (1) : 43-50.

Pujawan, I Nyoman. (2005). Supply Chain Management. Surabaya : Guna Widya.

Suharjito, Machfud, Haryanto, B., Sukardi, Marimin. (2011). Permodelan Optimasi Mitigasi Risiko Rantai Pasok Produk/Komoditas Jagung. Agritech 31 (3) : 215-227.

Ulfah,M., Maarif, M.S., Sukardi, Raharja, S. (2015). Analisis dan Perbaikan Manajemen Risiko Rantai Pasok Gula Rafinasi dengan Pendekatan House of Risk. Jurnal Teknik Industri Pertanian, 26 (1) : 87-103. 